
\title{
25 Research Soure \\ An Operative Laboratory Investigation of Bioconversion Route From Waste Coal to Natural Energy
}

\section{Priyanka Basera}

The Energy and Resources Institute

Meeta Lavania ( $\sim$ meetal@teri.res.in )

The Energy and Resources Institute https://orcid.org/0000-0002-2313-6408

Omkar shinde

TATA Steel Ltd Tisco General Office

Supriya Kumar Sarkar

TATA Steel Ltd Tisco General Office

\section{Banwari Lal}

The Energy and Resources Institute

\section{Research Article}

Keywords: waste coal, modified medium, reactivated microbial consortia, methane, analytical methods

Posted Date: August 20th, 2021

DOI: https://doi.org/10.21203/rs.3.rs-805232/v1

License: (c) (i) This work is licensed under a Creative Commons Attribution 4.0 International License. Read Full License

Version of Record: A version of this preprint was published at Annals of Microbiology on March 16th, 2022. See the published version at https://doi.org/10.1186/s13213-021-01659-z. 


\section{Abstract}

Purpose: In the present research, the potential of reactivated consortium for the methane production consuming waste coal as a carbon source $(1 \% \mathrm{w} / \mathrm{v})$ in the modified media at mesophilic temperature $\left(37^{\circ} \mathrm{C}\right)$ was determined.

Methods: Media modification was conducted for the enhancement of methane production by selecting three different components from the two media i.e. Methanosprillium sp producing media (MSP) and Methane producing bacteria media (MPB). From MSP medium; $\mathrm{C}_{2} \mathrm{H}_{2} \mathrm{NaO}_{2}$ (sodium acetate), $\mathrm{KH}_{2} \mathrm{PO}_{4}$ (potassium dihydrogen the phosphate) and $\mathrm{NaHCO}_{3}$ (sodium bicarbonate) whereas from MPB medium; yeast extract, peptone, and $\mathrm{NH}_{4} \mathrm{Cl}$ (ammonium chloride) were selected in the range of 0.5-2.5 ( $\left.\mathrm{g} / \mathrm{l}\right)$. Analytical assay i.e Fourier Transform Infrared Spectroscopy (FTIR) and Gas Chromatography Mass Spectrophotometry (GCMS) and Scanning electron microscopy (SEM) were conducted. Further, compatibility study and pathogenicity was performed.

Results: In the present study reactivated consortia was used therefore key components of the media were modified. In case of MPB medium: $2 \mathrm{~g} / \mathrm{I}$ of yeast extract, $2 \mathrm{~g} / \mathrm{l}$ peptone and $1 \mathrm{~g} / \mathrm{l} \mathrm{NH} \mathrm{H}_{4} \mathrm{Cl}$ showed the promising results. Whereas, for MSP medium: $1 \mathrm{~g} / \mathrm{l}$ of $\mathrm{KH}_{2} \mathrm{PO}_{4}, 0.5 \mathrm{~g} / \mathrm{l}$ of $\mathrm{NaHCO}_{3}$ and $1.5 \mathrm{~g} / \mathrm{l}$ of $\mathrm{C}_{2} \mathrm{H}_{2} \mathrm{NaO}_{2}$ were noted to be the suitable range for methane production. Analytical studies confirmed the presences of $-\mathrm{OH}$ and aliphatic groups which majorly belongs to alkane, alkene, and phenol derivatives compounds whereas Scanning electron microscopy (SEM) studies delineated the active interaction of bacteria with coal particles. In addition, a compatibility study was performed and their successful results aid in the future approach of field implementation. Further, pathogenicity data indicated the non-virulent and non-toxic nature of the consortia.

Conclusions: Production of waste coal is one of the most problematic and common activities of the mining industry. They release toxic substances into the environment (water, air, and soil) and damage the local biodiversity. Therefore, the generation of biogenic methane from waste coal is an environmentally friendly approach to overcome this problem.

\section{Introduction}

Low calorific value coal-generated from the coal mining industries is identified as waste coal or low-grade coal. Sometimes these are considered as a discarded coal; they generally form piles near the industries and appear as dark hills or unproductive small mountains. Waste coal usually creates metal leaching problems such as; iron, manganese, and aluminum in the water and further causes water pollution. It is also responsible for acid drainage. As these piles easily catch fire they release toxic gases in the air and cause air pollution (www.energyjustice.net). Therefore, controlled production of methane from the waste coal is an economically valuable solution. Methane is one of the clean natural forms of energy which fulfills the need of many industries and households activity with less waste to the environment (Li et al., 2020). However, consistently expanding worldwide energy demands and limited fossil fuel sources has 
created enormous pressure for developing sustainable energy source for hydrocarbons (Gupta and Gupta 2014). Energy sources with low carbon emission, such as methane gas, are becoming important these days (Caposciutti et al., 2020).

Methane is usually trapped in the coal therefore its production becomes an alternative mode for the energy generation. Methane can be produced by thermogenic (abiogenic) and biological (biogenic) processes. Thermogenic, occurring in subsurface carbon deposits at early or late coalification stages by the thermal cracking whereas biological occurs usually at or near the earth's surface using microorganisms (Chena et al., 2017; Wang et al., 2019). Biogenic methane is the result of complex biochemical reactions by groups of bacteria and archaea during the decomposition of organic matter in the anoxic environment. Due to the complexity in process of biogenic methane production, the procedure was poorly understood, but still, they are pervasive in nature (Wolfe 1996). In the past few years, numerous researchers have investigated the biodiversity of microbes residing in the coal seams and coal beds. The reported bacteria mainly belong to the three functional different trophic groups: hydrolytic fermentative, syntrophic acetogenic, and methanogenic bacteria (Boone 1991; Ritter et al., 2015). Hydrolytic fermentative and syntrophic acetogens, hydrolyse complex polymers (cellulose, polysaccharide, and protein) into monomers (fatty acids, sugars, amino acids, carbon dioxide, acetate, and hydrogen). These monomers are further utilized by methanogens to produce methane as depicted in Fig. 1 (Conrad et al., 1999; Davis 2018). Although, according to Enzmann et al.,2018, the universal mode of methane production is a hydrogen mediated reduction of carbon dioxide. Various, environmental ( $\mathrm{pH}$, salinity, temperature) and nutritional factors (inorganic and organic) can affect the process of methanogenesis (Boone 1991).

It has been reported that the rate of methane production depends on the maturity and functional microbial communities present in the coal. Configuration-wise, coal consists of condensed aromatic ring which makes it a complex and heterogeneous material. Lignin monolignols were considered as the main compound, whereas aromatic compounds considered as a derivative of coal which can further be substituted with hydroxyl, methoxy, and carboxyl groups. According to Mayumi et al., 2016 immature coals were commonly abundant in the methoxy groups. Since methanogenesis from coal tends to occur in immature coal rather than in mature coal, it was believed that coal-bed microorganisms may produce methane from methoxy groups (Rathi et al., 2015). Unlike coal mining, which required mechanical methods of extraction and processing, biogenic methane production is one of the conventional methods and found to be economically viable and environment-friendly.

In the present study, we proposed an approach for (1) the development and demonstration of the bioconversion process for the generation of methane from waste coal received from Tata Steel Jamshedpur, India. (2) Study the potential of developed consortia by modifying nutrient media (MSP and MPB) further, the analytical parameter of coal examination was conducted using FTIR, GCMS, followed by SEM techniques and, (3) pathogenicity assay and compatibility study was conducted. This study would help in proposing the suitable strategy for possible future in field implementation. 


\section{Methods}

\subsection{Sample Collection and Characterization}

In the present study, waste coal was received from Tata Steel, Jamshedpur, India. Sampling was performed in sterilized bottles and stored at ambient temperature and further transported to the laboratory (The Energy and resources of Institute, New Delhi). Characterization of waste coal was conducted in terms of ash, moisture, volatile matter, and fixed carbon along with the specific carbon, hydrogen, nitrogen, sulfur, and oxygen (CHNSO). CHNSO analysis was determined using IS: 1350/ American Public Health Association guideline (Rathi et al., 2015).

\subsection{Enrichment and Modification of Media}

To study the potential of developed consortia at mesophilic condition, four enrichment cycles were performed in two different media specific for different species of methanogens. MSP (Methanosprillium sp.) and MPB (Methanogen specific). The MSP medium contained ( $\mathrm{g} / \mathrm{l}$ in de-ionized water): $\mathrm{KH}_{2} \mathrm{PO}_{4}, 0.5$ g; MgSO.7H $\mathrm{H}_{2} \mathrm{O}, 0.4 \mathrm{~g} ; \mathrm{NaCl}, 0.4 \mathrm{~g} ; \mathrm{CaCl}_{2} .2 \mathrm{H}_{2} \mathrm{O}, 0.05 \mathrm{~g} ; \mathrm{FeSO}_{4} .7 \mathrm{H}_{2} \mathrm{O}, 0.002$ g; yeast extract, $1 \mathrm{~g} ; \mathrm{C}_{2} \mathrm{H}_{2} \mathrm{NaO}_{2}, 1$ g; sodium formate, $2 \mathrm{~g} ; \mathrm{NaHCO}_{3}, 4 \mathrm{~g}$; resazurin, $0.001 \mathrm{~g}$; L-cysteine $\mathrm{HCl}, 0.5 \mathrm{~g}$ at pH $7.00 \pm 0.2$ (Lavania et al., 2014). The composition of MPB medium ( $\mathrm{g} / \mathrm{l}$ in de-ionized water) was: $\mathrm{K}_{2} \mathrm{HPO}_{4}, 0.3 \mathrm{~g} ; \mathrm{KH}_{2} \mathrm{PO}_{4}, 0.3 \mathrm{~g}$; $\mathrm{NH}_{4} \mathrm{Cl}, 0.5 \mathrm{~g} ; \mathrm{MgSO}_{4} \cdot 6 \mathrm{H}_{2} \mathrm{O}, 0.2 \mathrm{~g} ; \mathrm{NaCl}, 1.0 \mathrm{~g}$; yeast extract, $1.0 \mathrm{~g}$; casein peptone, $1.0 \mathrm{~g}$; resazurin, $0.001 \mathrm{~g}$; $\mathrm{L}$-cysteine $\mathrm{HCl}, 0.5 \mathrm{~g}$ at $\mathrm{pH} 7.00 \pm 0.2$. The $\mathrm{pH}$ was adjusted with $1 \mathrm{M} \mathrm{NaOH} / 1 \mathrm{M} \mathrm{HCL}$. The medium was then boiled under a stream of oxygen-free nitrogen gas to remove all the dissolved oxygen. After cooling under continuous nitrogen flow, the medium was dispensed into $100 \mathrm{ml}$ serum bottles containing $1 \% \mathrm{w} / \mathrm{v}$ of waste coal (used as a carbon source). The bottles were sealed with butyl rubber stoppers and sterilized at $121^{\circ} \mathrm{C}$ for $20 \mathrm{~min}$. All the experiments were performed in triplicates, the inoculated serum $(10 \%$ inoculum) bottles were incubated at $37^{\circ} \mathrm{C}$ for $15-20$ days.

For maximum production of methane, media modification studies were performed in which three components from two media (MSP and MPB) were selected in a range of 0.5-2.5 g/l. Ingredients from MPB medium were; yeast extract, peptone, and $\mathrm{NH}_{4} \mathrm{Cl}$ and from MSP medium; Sodium acetate, $\mathrm{KH}_{2} \mathrm{PO}_{4}$, and $\mathrm{NaHCO}_{3}$ were considered. Test range for ingredients was varied from $0.5,1.0,1.5,2.0$ to $2.5 \mathrm{~g} / \mathrm{l}$. The medium was boiled under the inert environment (using nitrogen gas). Inoculated coal bottles were kept at $37^{\circ} \mathrm{C}$ and gas was monitored in 5th, 10th, 15th, and 20th day. Further, to study the effect of different nitrogen source on methane production CSL (corn steep liquor) and urea was also used. Modified medium contained (g/l in de-ionized water): $\mathrm{KH}_{2} \mathrm{PO}_{4}, 1 \mathrm{~g} ; \mathrm{NH}_{4} \mathrm{Cl}, 1 \mathrm{~g} ; \mathrm{MgSO}_{4} \cdot 6 \mathrm{H}_{2} \mathrm{O}, 0.2 \mathrm{~g} ; \mathrm{NaCl}, 1.0 \mathrm{~g}$; yeast extract, $2 \mathrm{~g}$; Peptone, 2; $\mathrm{NaHCO}_{3}, 0.5 \mathrm{~g}$; Sodium acetate, $1.5 \mathrm{~g}$; resazurin, $0.001 \mathrm{~g}$; L-cysteine $\mathrm{HCl}, 0.5$ $\mathrm{g}$ at $\mathrm{pH} 7.00 \pm 0.2$. Resazurin was added as an oxygen indicator (resazurin has a pink color at redox potentials of about $150 \mathrm{mV}$ ). The pH was adjusted with $1 \mathrm{M} \mathrm{NaOH} / 1 \mathrm{M} \mathrm{HCL}$. The media was prepared anaerobically through nitrogen sparging. The medium was used for bacterial reactivation and scale-up analysis. 


\subsection{Reactivation of developed Consortia (Reactivated Consortia)}

To study the efficiency of developed consortia, reactivation was conducted in the modified medium with $1 \%$ waste coal $(\mathrm{w} / \mathrm{v})$. To reactivate methanogens, an aliquot of developed consortia $(5 \mathrm{ml})$ was added in $10 \mathrm{ml}$ of the modified medium. Further, after obtaining 0.5 MacFarland standard turbidity of bacterial growth which was equivalent to $1.5 \times 106 \mathrm{CFU} / \mathrm{ml}$, subculturing was performed for inoculum preparation which was considered as reactivated consortium (Wayne 2003). All the inoculated serum bottles were incubated at $37^{\circ} \mathrm{C}$ for $15-20$ days.

\subsection{Microbial Community present in Reactivated Consortia}

To identify the enriched/isolated microbial community from developed consortia, total genomic DNA was extracted and purified using a PowerSoil DNA Isolation Kit (MoBio,) as instructed in the manufacturer's protocol. PCR amplification was done with universal bacterial primers 27F (5'-AGA GTT TGA TCC TGG CTC AG-3') and 1492R (5'-ACG GCT TAC CTT GTT ACG CTT-3') as well as archaeal primers 109f (5'-ACK GCT CAG TAA CAC GT-3') Met 915R (3'GTG CTC CCC CGC CAA TTC CT-5') (Lavania et al., 2014). 97\% of the similarity was accounted for in the identification of microbial populations from the assessed microbial consortia (Fuerteza et al., 2018).

\subsection{Analytical Analysis of Sample \\ 2.5.1 Fourier Transform Infrared Spectroscopy (FTIR)}

FT-IR was carried out to identify the functional groups present in the bacterially degraded coal sample. Functional group was characterized by using Fourier Transform Infrared Spectroscopy (Perkin Elmer). All spectra were recorded in an absorbance scale with a mid-measuring region of $400-4000 \mathrm{~cm}^{-1}$ (midinfrared range). The resolution was set at $4 \mathrm{~cm}^{-1}$ with 64 scans per spectrum.

\subsubsection{Gas Chromatography (GC)}

In the present analysis, concentration of gas produced in the headspace (methane and carbon-dioxide in $\%$ ) of media bottles were analyzed with GC 7890A Agilent Ltd. USA equipped with a packed stainless steel column $(2 \mathrm{~m} \times 2 \mathrm{~mm}$ id NUCON, INDIA) with a thermal conductivity detector (TCD). Where, argon acts as the carrier gas with flow rate of $1.0 \mathrm{ml} / \mathrm{min}$. The operating temperatures of the injection port, oven and the detector were 100,50 and $150^{\circ} \mathrm{C}$ respectively (Rathi et al., 2015). The incubated cultures were tested for $\mathrm{CH}_{4}$ and $\mathrm{CO}_{2}$ production after 15-20 days by taking $0.5 \mathrm{ml}$ of headspace gas samples from the anaerobic serum bottles using gas-tight syringe.

\subsubsection{Gas Chromatography Mass Spectrophotometry (GCMS)}


The sample was analyzed using GCMS (model GC-7890A, Agilent Ltd., United States) equipped with DBWAX capillary column. Helium was used as the carrier gas. Temperature ranges between $230-325^{\circ} \mathrm{C}$. Initially, column temperature was set at $70^{\circ} \mathrm{C}$ and further increased to $325^{\circ} \mathrm{C}$. Diluted sample $(1 / 50$ in methanol) of $0.1 \mu \mathrm{l}$ was used. The components were identified on the basis of their mass spectra using NIST (National Institute for Standards and Technology) library data base.

\subsubsection{Scanning Electron Microscopy (SEM)}

Interactions between bacterial species and coal were studied by Scanning Electron Microscopy (Carl Zeiss) (Hayat 2000). Under aseptic conditions, sample was absorbed for 2 to $4 \mathrm{~h}$ in $2.5 \%$ glutaraldehyde solution. $0.1 \mathrm{M}$ phosphate buffer was used for primary washing where $\mathrm{pH}$ maintained up to 7.2 further sample was dehydrated with ethanol solution in a series of $10-100 \%$ followed by acetone. Samples were air dried overnight and coated with thin layer of metal (gold and palladium).

\subsection{Pathogenicity Test}

The pathogenicity test of reactivated consortia was examined by acute oral toxicity under EPA 712-C-96322 OPPTS 885.3550 guidelines at National Toxicology Centre (APT Testing and Research Pvt. Ltd.), Pune. Twelve mice ( 6 male and 6 female) were designated to the dose groups: control and test $(1 \mathrm{ml}=$ $1.0 * 10^{8} \mathrm{CFU}$ ) were administrated by the gauge to six mice per sex. The mice were fasted overnight and 2 $\mathrm{h}$ after administration of the test material.

The mice were observed for 21 days after dosing. At the end of the inspection period, the surviving experimental animals were sacrificed for testing. Gross necropsy was performed and all animals were carefully examined for the presence of anaerobic bacteria. The body weight was recorded. All animals were observed for mortality throughout the observation period. RBC (red blood cell), WBC (white blood cell), Hemoglobin, Packed cell Volume, Glucose, BUN (blood urine nitrogen), Total Proteins and Albumin were studied on 21 st day of the experiment.

\subsection{Compatibility Studies}

Before field implementation test, compatibility studies were conducted in the lab. In this analysis obtained tube well water was used for media preparation (available near the washeries in Jharia). Experiment was conducted in four sets; in set 1: anaerobic condition was maintained without autoclaving (referred as S-A), in set 2: anaerobic condition was maintained with proper sterilization (referred as $S+A$ ), in set 3: aerobic condition without autoclaving (referred as US-A) and in set 4: aerobic condition with autoclaving (referred as US $+A$ ). While preparing the media no precipitation was observed with commercial grade of chemicals in tube well water. In all sets waste coal $(1 \% \mathrm{w} / \mathrm{v})$ was used. After inoculating with inoculum (10\%) all sets were incubated at $37^{\circ} \mathrm{C}$ for $15-20$ days.

\subsection{Statistical Analysis}

All the experiments were performed in triplicates. The data points are average of the triplicate \pm standard deviation (less than $5 \%$ of average) and calculated significance $p$ values are $\leq 0.05$. 


\section{Results}

\subsection{Coal Characterization}

The detailed analysis of collected waste coal samples in terms of ash, moisture, volatile matter and fixed carbon along with the specific carbon, hydrogen, nitrogen, sulfur and oxygen (CHNSO) was determined as per the guidelines of ASTM standard (Table S1) (Rathi et al., 2015). Proximate analysis data showed that waste coal contains $0.49 \%$ of moisture, $14.85 \%$ of volatile matter along with high $42.52 \%$ of ash and $42.14 \%$ of fixed carbon. The calorific value of waste coal was $4092 \mathrm{kcal} / \mathrm{kg}$. Obtained data of waste coal indicated the significant potential in the bioconversion process of methane. The ultimate analysis of the waste coal samples showed $44.71 \%$ of carbon, $2.55 \%$ of hydrogen, $0.04 \%$ of nitrogen, $0.28 \%$ of sulfur, and $9.41 \%$ of oxygen.

\subsection{Enrichment Studies}

Figure 2 illustrated the gas production (methane and carbon dioxide) in all four successive enrichment cycles in both the specific media (MSP and MPB) at $37^{\circ} \mathrm{C}$. However, in the MSP medium, an increase in methane generation was observed from $9.99 \%$ to $27.4 \%$ in 1st and 4th enrichment cycle respectively whereas; carbon-dioxide was decreased from $5.2 \%$ to $4.9 \%$. Further, $\mathrm{CH} 4$ : $\mathrm{CO} 2$ (methane: carbon-dioxide) the ratio was ranging from 1.8 to 5.5. Similarly, in the case of MPB medium, rises in methane generation was noted from $12 \%$ to $29.2 \%$, and reduction in carbon-dioxide from $6.6 \%$ to $4.5 \%$ in the 1 st and 4 th cycles respectively. Also, $\mathrm{CH} 4: \mathrm{CO} 2$ the ratio was ranging from 2.0 to 6.4. In the developed consortium, both media showed almost the similar trends in methane production (29.2\% in MPB and $27.4 \%$ in MSP)

\subsection{Modification of Nutrient Media}

The modification study was performed to enhance the biogenic methane content. Methane production by consortia was tested with different sets of MPB and MSP media. Gas was monitored at interval of 5 days during incubation period.

Figure 3 data demonstrated the methane production in selected range of components form MPB medium in with and without coal sets. Selected components were peptone (Fig. 3A), yeast extract (Fig. 3B), and $\mathrm{NH}_{4} \mathrm{Cl}$ (Fig. 3C) in a range between $0.5,1.0,1.5,2.0$ to $2.5 \mathrm{~g} / \mathrm{l}$ with waste coal (1\% w/v). In this experiment, it was observed that methane was increased up to a concentration after that production was not supportive. In case of yeast extract and peptone, $2 \mathrm{~g} / \mathrm{I}$ was obtained to be preeminent concentration for methane production ( $42.3 \%$ and $35.23 \%$ respectively) whereas, in $\mathrm{NH}_{4} \mathrm{Cl} ; 1 \mathrm{~g} / \mathrm{l}$ was showed the respectable result with $38.1 \%$ of methane after 20 th day of incubation. Figure 3D depicted the methane generation in without coal set. Methane was observed at 20th day of incubation. By comparing the data of with and without coal, it was noted that methane generation was more in case of set containing coal.

Further in MSP medium (Fig. 4), $1 \mathrm{~g} / \mathrm{l}$ of $\mathrm{KH}_{2} \mathrm{PO}_{4}$ (Fig. 4A), $0.5 \mathrm{~g} / \mathrm{l}$ of $\mathrm{NaHCO}_{3}$ (Fig. 4B) and $1.5 \mathrm{~g} / \mathrm{l}$ of $\mathrm{C}_{2} \mathrm{H}_{2} \mathrm{NaO}_{2}$ (Fig. 4C) indicated the suitable range for methane production with $23.34 \%, 23.45 \%$ and $34.22 \%$ 
respectively after 20th day of incubation. Figure 4D showed the methane production without coal after 20th day. As the range increased for selected components, methane production was increased up to particular range beyond which it seems to be not favorable. Data obtained in with and without coal sets, confirmed that coal was participating actively in methane generation. With coal, methane generation was observed to be more. Further, in modification study with different nitrogen source on methane generation was studied with CSL and Urea components. Obtained data was not favorable for methanogenesis as represented in Figure S1.

\subsection{Identification of Microbial Community Present in Reactivated Consortia}

As shown in Fig. 5, reactivated consortia from developed consortia contained majority of similar community as described in published manuscript (Lavania et al., 2014). Both bacterial and archaeal domain was noted. Methanoculleus thermophiles was observed as the major archaeal species in Methanoculleus sp. Apart from Methanoculleus sp., Comamonas sp. was also obtained. In reactivated consortia majority of species were similar (Methanoculleus sp. and Comamonas $s p$.). Along with archaeal domain, bacterial domain was also noted in reactivated consortia which were comprised of fermicutes (Clostridium sp.) and proteobacteria (Pseudomonas $s p$.). The obtained microbial community was able to generate methane at mesophilic condition.

\subsection{Analytical Analysis of Sample (FT-IR and GC-MS)}

In order to understand the functional groups present in the coal sample, FITR analysis was performed as shown in Fig. 6A. Spectra fragment lies between $1600-1800 \mathrm{~cm}^{-1}$ was attributed to aromatic group ( $\mathrm{C}=$ C). Further the stretching of $3000-2800 \mathrm{~cm}^{-1}$ corresponded to $-\mathrm{OH}$ and $-\mathrm{NH}$ groups. The presence of aliphatic groups (methyl and methylene) illustrated by spectra range from $2400-2000 \mathrm{~cm}^{-1}$. Smaller peaks beyond $1600 \mathrm{~cm}^{-1}$ were represented the presence of mineral compositions in the sample (Damin et al., 2010; Zhou et al., 2014; Singh et al., 2017).

Previous reports stated the presence of low molecular weight hydrocarbons in coal sample. Where, GCMS plays the important role in identifying those compounds (Fan et al., 2013). The organic moiety present in coal was observed to be cyclic and acyclic hydrocarbons mainly alkanes, alkenes and derivatives of phenols (Table S2). Figure 6B illustrated the fragmentation pattern of compounds present in the sample. Major peaks were recorded at RT 27.39, 37.74, 44.32, 47.05 and 61.00 which corresponds to 2,4-Di-tertbutyl phenol, 5-Octadecene, E-15 Heptadecenal, 1-Nonadecanol and Cyclotetracosane respectively (https://pubchem.ncbi.nlm.nih.gov/compound/2_4-Di-tert-butylphenol).

\subsection{Scanning Electron Microscopy (SEM)}

SEM images depicted the coal particles were destructed and reduced in sized after the bacterial intervention (Fig. 7A and 7B). The reduced sized coal provided the large surface area which makes 
adherence easy for the bacteria. Morphology of bacteria and bacterial interaction with coal particles were clearly visible in Fig. 7C, where red arrows indicated the presence of bacteria and black arrows showed the coal particles. Mixed natures of anaerobic bacteria were noted, where rod and coccus shaped were observed and presences of bacteria were recorded in the clusters form.

\subsection{Pathogenicity Assessment}

Reactivated consortia ( $1 \mathrm{ml}$ of dose) did not show any case of mortality in the treated mice (both male and female). All the mice were appeared to be normal and showed no clinical signs of intoxication after dosing till the end of the study. No statistically significant difference in the hematological and blood chemistry parameters (Red Blood Cells, White Blood Cells, Hemoglobin, Packed Cell Volume, BUN, Albumin, Total protein and Glucose) was observed in the test group. After evaluating the test groups with control group, there were no numerically decreased in body weight was observed. The results from the necropsy revealed no abnormalities in the test group when compared with the control group animals. The consortia did not induce any gross pathological alterations, in experimental models during their necropsy. The sacrificed mice's were thoroughly examined and were found to be completely free from any live anaerobic bacteria. After analyzing the data, reactivated consortia were considered to be non-toxic and non-virulent. Hence, it is safe for field implementation (Table S3-S6).

\subsection{Compatibility Studies}

Compatibility study of waste coal in modified media with reactivated consortia was executed as represented in Fig. 8. Methane and carbon-dioxide was observed in all experimental sets with different percentage. In set 1 and set 2, significantly high amount of methane and low amount of carbon-dioxide was noticed with $51.6 \%, 49.91$ methane and $6.25 \%, 7.61 \% \mathrm{CO}_{2}$ respectively. In set 3 , methane was found to be significantly reduced which was $13.2 \%$ with $7.21 \%$ of carbon-dioxide. Whereas, in set 4 ; negligible amount of methane $(0.54 \%)$ was observed with $7.56 \%$ of carbon-dioxide.

\section{Discussion}

Bio-conversion of coal to methane can be considered as a healthy and feasible approach for the environment. As studies reported by $\mathrm{Ge} \mathrm{H}$ et al., 2016; Ribeiro et al., 2012; Hao et al., 2016 suggested the toxic nature of waste coal piles generated near the industries during coal mining. Therefore, through this study recovery of significant methane was observed using waste coal.

In the present research, microbes from the developed consortia were reactivated and further used as a source for biogenic methane production. Figure 2 showed the production of methane gas $(29.2 \%$ in MBP and $27.4 \%$ in MSP) along with the carbon-dioxide (5.2 \% in MBP and $6.6 \%$ in MSP). Therefore, to maintain the composition of gas (majorly methane) modification studies were conducted by selecting two specific media (MPB and MSP). In MPB medium concentration of yeast extract, peptone and $\mathrm{NH}_{4} \mathrm{Cl}$ whereas in MSP medium concentration of $\mathrm{C}_{2} \mathrm{H}_{2} \mathrm{NaO}_{2}, \mathrm{KH}_{2} \mathrm{PO}_{4}$ and $\mathrm{NaHCO}_{3}$ were altered. Modification provided promising results for methane generation in the scale-up analysis. 
Each selected component plays a vital role in the methanation process as depicted in Fig. 3 and Fig. 4. Selected components from the MPB medium were; yeast extract, peptone, and $\mathrm{NH}_{4} \mathrm{Cl}$ which behaves like a common complex and defined nitrogen source in the medium. Previous studies have been examined for their potential to enhance coal-to-methane conversion (Verstraete et al., 1984; Wagner et al., 2012; Davis et al., 2018). Preceding researches also investigated urea and CLS (corn steep liquor) compounds as a respectable nitrogen source (Yang et al., 2014; Tan et al., 2016). But in this investigation yeast extract, peptone and $\mathrm{NH}_{4} \mathrm{Cl}$ showed promising results (Fig. 3) whereas urea and CLS were not found to be that effective (Figure S1). In MSP medium; $\mathrm{C}_{2} \mathrm{H}_{2} \mathrm{NaO}_{2}, \mathrm{KH}_{2} \mathrm{PO}_{4}$, and $\mathrm{NaHCO}_{3}$ were elected. According to Ulrich \& Bower 2008 study, $\mathrm{C}_{2} \mathrm{H}_{2} \mathrm{NaO}_{2}$ was considered as an essential ingredient for methanogenesis. Furthermore, $\mathrm{pH}$ also plays an important role in the methanation process. And with the proper buffering system optimized pH can be achieved (Gupta and Gupta 2014; Yang et al., 2018). $\mathrm{KH}_{2} \mathrm{PO}_{4}$ and $\mathrm{NaHCO}_{3}$ were considered as the chief components in maintaining the $\mathrm{pH}$ of the medium (Eduok et al., 2018). As the selected components of MPB and MSP media had a significant role in the methane generation process, they were varied in a certain range $(0.5-2 \mathrm{~g} / \mathrm{l})$ for the modifying study. The reactivated consortium showed the highest methane production at $37^{\circ} \mathrm{C}$ in the modified medium when waste coal was used as a carbon source. By comparing Fig. 2, Figs. 3 and 4 noteworthy differences in methane generation were noted. In the case of MBP and MSP media, methane production was observed to be 29.2 $\%$ and $27.4 \%$ respectively (Fig. 2), whereas in modified medium methane generation was in the range of 40-50\%. These results prove that the nutrient amendment was a successful strategy for methane production.

Figure 3 and Fig. 4 data also illustrate the importance of coal in the medium. By observing with coal (Fig. 3A, 3B, 3C, 4A, 4B, 4C) and without coal (Fig. 3D, 4D) data sets, maximum production of methane after the 10th day of incubation was noticed in sets having coal. This study emphasizes the importance of methane production in a low incubation period as previous literature, on waste coal showed more than a month of the incubation period (Opara et al., 2012; Gupta and Gupta 2014).

The microbial community present in the reactivated culture showed a 95\% similarity with developed consortia (Fig. 5). Both bacterial and archaeal domain was observed. The bacterial domain was comprised of firmicutes (Clostridium beijerinckii and Clostridium sp.) and Proteobacteria (Pseudomonas sp. and Comamonas sp.) Similar species was reported by many scientists for methane generation (Bi et al., 2017). Further, methanation by similar species at $23^{\circ} \mathrm{C}$ was also observed (Fuerteza et al., 2018). The archaeal domain includes majorly Methanoculleus sp. which are responsible for methane production was also noted. According to Zellner et al., 1998; Zhu et al., 2011 research on methanation similar archeal species were reported. The genera Methanoculleus were related to the family Methanomicrobiaceae, this family contains methanogens of highly irregular coccoid shape with optimal growth temperature 25$60^{\circ} \mathrm{C}$ (Spring et al., 2005). By looking into the mechanism of methane production by the microbial community; it was reported by previous researchers that acetogenic microorganisms oxidize organic compounds partially into acetate which was further consumed by methanogens for methane production (Kushkevych et al., 2017) (Fig. 1). Clostridium sp. is a well-known acetogenic species; it utilized the 
organic component from the environment and produces acetate (Schmidt et al., 1985). Further, the byproduct of Clostridium sp. (acetate) is consumed by methanogens for methane production.

In analytical studies, FTIR provided the details of functional groups present in the coal sample (Fig. 6A). As reported by Reddy and vinu 2016; Sonibare et al., 2012 organic part of coal contains aromatic, aliphatic, and oxygen groups. The spectrum obtained from FTIR of coal sample attributed the presence of $-\mathrm{OH}$ and $\mathrm{C}=\mathrm{C}$ groups. The presence of aromatic $\mathrm{C}=\mathrm{C}$ stretch demonstrated that the carbon content was more in the sample. The CHNS data also proved the same, the possible reason for high carbon content could be the reduction of oxygen due to the conversion of $\mathrm{C}=\mathrm{O}$ to $\mathrm{CH}_{2}$ or decarboxylation (Manoj et al., 2009). FTIR spectra reported by Li et al., 2018; Zhang et al., 2018 showed similar trends. Further, extending the analysis in identifying the chemical groups of coal sample GC-MS was considered as a powerful tool (Fig. 6B). Aliphatic compounds present in the sample contained various range of hydrocarbons, alkene, and cyclic or acyclic compounds (Table S2). By observing the fragmentation pattern, the peak at RT 24.4 corresponds to 2,4-Di-tert-butyl which has a role in bacterial metabolites (National Center for Biotechnology Information NIH). Damin et al., 2010; Shi et al., 2013 demonstrated the presence of alkenes, cyclic, and acyclic organic species in the coal sample. FTIR and GCMS data revealed that bacteria can utilize the components from coal for the production of methane. Further, an SEM micrograph depicted the interaction between coal and bacteria (Fig. 7). Stephen et al., 2014 study, explained the interactions between bacteria (rod-shaped, anaerobic) and coal. According to Wang et al., 2017 SEM images illustrated the growth of microflora on the surface of coal and their effects on the coal surface in terms of morphological change.

Further, pathogenicity data of consortia revealed that consortium was safe for the large scale analysis or the field trial (Table S3-S6). In the experiment of compatibility (Fig. 8) potential of waste coal for methane production was noted significantly. The nitrogen sparged sets; set 1 and set 2 demonstrated the maximum production of methane $(51.6 \%$ and $49.91 \%$ respectively) this study also proved that an anaerobic environment is a vital factor for methanogenesis. Whereas, sets without sparged (set 3 and set 4) showed considerably low and negligible methanation ( $13.2 \%$ and $0.54 \%$ respectively). This research provides an idea for establishing a feasible way for creating a pollution-free environment from waste coal to clean and natural energy.

\section{Conclusions}

Our study emphasizes the production of renewable energy (methane) from the waste piles of coal present near the coal mining area. This study proves the enhancement of methane generation in the presence of coal containing medium. The data of FTIR and GCMS illustrated the complex nature of the coal sample. Moreover, active interactions of bacteria with coal particles were detected in the SEM micrograph. Further, pathogenicity assay explained the non-pathogenic nature of the consortium. The results highlighted the potential of the bioconversion process from waste to renewable energy generation. This study can be seen as a promising alternative method for energy generation through coal waste piles. 


\section{Declarations}

\section{ETHICAL STATEMENT}

\section{Ethics approval and consent to participate:}

The pathogenicity was studied by acute oral toxicity under EPA 712-C-96-322 OPPTS 885.3550 guidelines. The study was performed at National Toxicology Centre (APT Testing and Research Pvt. Ltd.), Pune.

\section{Consent for publication:}

Not applicable

\section{Availability of data and materials:}

Not applicable

\section{Completing Interest:}

The authors report no declarations of interest.

\section{Funding:}

The authors declare that this study received funding from TATA Steel Ltd (IN-DL13508522907519P) Tisco General Office, Bistupur, and Jamshedpur.

\section{Author Contributions:}

PB and ML designed the experiments. PB conducted experiments as per design \& data generation further wrote the manuscript. ML critically reviewed the manuscript. OS, SKS involved in technical guidance in waste coal washeries and their selection and characterization of waste coal. BL provided the resources for performing experiments. All authors read and approved the final manuscript.

\section{Acknowledgments:}

Authors are thankful to TERI for providing the infrastructural facilities for executing the present study. The authors would also like to acknowledge the facility of TDNBC and TERI for GC-MS, FTIR and SEM analysis. The funder had the involvement in technical guidance in waste coal washeries selection and physico chemical properties data interpretations of waste coal.

\section{References}

1. Bi, Z., Zhang, J., Park, S., Harpalani, S., and Liang, Y. (2017). A formation water-based nutrient recipe for potentially increasing methane release from coal in situ. Fuel 209, 498-508. 
2. Boone, D. R., (1991). Ecology of methanogenesis. In: Rogers J.E. \& Whitman W.B. (eds.), Microbial Production and Consumption of Greenhouse Gases: Methane, Nitrogen Oxides and Halomethanes, American Society for Microbiology, Washington, DC, 57-70.

3. Chena, T., Zheng, H., Hamilton, S., Rodrigues, S., Golding, D. S., and Rudolpha, V. (2017). Characterisation of bioavailability of Surat Basin Walloon coals for biogenic methane production using environmental microbial consortia. Int. J. Coal Geol 179, 92-112.

4. Clark, B., (2007). Heavy oil, extra-heavy oil and bitumen unconventional oil working Document of the NPC Global Oil and Gas Study. Topic paper 22, 18 July.

5. Conrad, R., (1999). Contribution of hydrogen to methane production and control of hydrogen concentrations in methanogenic soils and sediments. FEMS Microbiol Ecol 28, 193-202.

6. Damin, T., Xiangyum, L., and Mingjie, D., (2010). CS2 extarction and FTIR and GC/MS analysis of a Chinese brown coal. Mining Science and technology 20, 0562-0565.

7. Davis, J. K., and Gerlach, R., (2018). Transition of biogenic coal-to-methane conversion from the laboratory to the field: A review of important parameters and studies. Int. J. Coal Geol 185, 33-43

8. Davis, K. J., Lu, S., Barnhart, E. P., Parker, A. E., Fields, M. W., and Gerlach, R., (2018). Type and amount of organic amendments affect enhanced biogenic methane production from coal and microbial community structure. Fuel 211, 600-608.

9. Eduok, S., John, O., Ita, B., Inyang, E., and Coulon, F., (2018). Enhanced biogas production from anaerobic co-digestion of lignocellulosic biomass and poultry feces using source separated human urine as buffering agent. Front. Environ. Sci6:67

10. Enzmann, F., Mayer, F., Rother, M., and Holtmann, D., (2018). Methanogens: biochemical background and biotechnological applications. AMB Expr 8, 1-22

11. Fan, X., Wei, X. Y., and Zong, Z.M., (2013). Application of gas chromatography/mass spectrometry in studies on separation and identification of organic species in coals. Fuel 109, 28-32

12. Fuerteza, J., Córdobab, G., McLennan, J. D., Adams, D. J., and Sparks, T. D., (2018). Potential application of developed methanogenic microbial consortia for coal bio-gasification. Int. J. Coal Geol188, 165-180

13. Ge, H., Feng, Y., Li, Y., Yang, W., and Gong, N., (2016). Heavy metal pollution diagnosis and ecological risk assessment ofthe surrounding soils of coal waste pile at Naluo Coal MineLiupanshui, Guizhou. Int J Min. Reclam Env 30,312-318.

14. Gupta, P., and Gupta, A., (2014). Biogas production from coal via anaerobic fermentation. Fuel 118, 238-242.

15. Hao, G., Yun, F., Fangfang, L., Yang, L., WenLia, Y., and Yin, Y., (2016). Soil diagnosis and land suitability assessment for vegetation restoration on coal waste piles in Liupanshui, Guizhou, China. Int J Min Reclam Env30, 209-216.

16. https://pubchem.ncbi.nlm.nih.gov/compound/2_4-Di-tert-butylphenol 
17. Kushkevych, I., Vítězová, M., Vítěz, T., and Bartoš, M., (2017). Production of biogas: relationship between methanogenic and sulfate-reducing microorganisms. Open Life Sci. 12, 82-91.

18. Lavania, M., Cheema, S., Sarma, P, M., Ganapathi, R., and Lal, B., (2014). Methanogenic potential of a thermophilic consortium enriched from coal mine. Int Biodeter Biodegr 93, 177-185.

19. Li, H.; Zuo, J.; Wang, L.; Li, P.; Xu, X. Mechanism of structural damage in low permeability coal material of coalbed methane reservoir under cyclic cold loading. Energies2020, 13, 519.

20. Li, J., Li, Z., Yang, Y., King, B., and Wang, C. (2018). Laboratory study on the inhibitory effect of free radical scavenger on coal spontaneous combustion. Fuel processing technology 171, 350-360

21. Manoj, B., Kunjomana, A, G., and Chandrasekharan. (2009). Chemical leaching of low rank coal and its characterization using SEM/EDAX and FTIR. JMMCE 8, 821-832.

22. Mayumi, D., Mochimaru, H., Tamaki, H., Yamamoto, K., and Yoshioka, H., et al., (2016). Methane production from coal by a single methanogen. Science. 354,222-225.

23. Opara, A., Adams, D. J., Free, M. L., McLennan, J., and Hamilton, J., (2012). Microbial production of methane and carbon dioxide from lignite, bituminous coal, and coal waste materials. Int. J. Coal Geol.96(97), 1-8.

24. Rathi, R., Priya, A., Vohra, M., Lavania, M., Lal, B., and Sarma, P. M., (2015). Development of a microbial process for methane generation from bituminous coal at thermophilic conditions. Int. J. Coal Geol 148, 25-34.

25. Rathi, R., Lavania, M., Singh, N., Sarma, P, M., and Kishore, P., et al., (2019). Evaluating indigenous diversity and its potential for microbial methane generation from thermogenic coal bed methane reservoir. Fuel 250, 362-372.

26. Reddy, B. R., and Vinu, R., (2016). Microwave assisted pyrolysis of Indian and Indonesian coals and product characterization. Fuel processing technology. 154, 96-103.

27. Ribeiro, J., Silva, T., Filho, J. G. M., and Flores, D., (2012). Polycyclic aromatic hydrocarbons (PAHs) in burning and non-burning coal waste piles. J Hazard Mater200,105-110.

28. Ritter, D., Vinson, D., Barnhart E., Akob, D, M., Fields, M, W., Cunningham A, S., Orem W., Mclntosh, J, C., (2015). Enhanced microbial coalbed methane generation: A review of research, commercial activity and remaining challenges. Int. J. Coal Geol. 146, 28-41.

29. Schmidt, R. L., and Cooney, C. L., (1985). Production of acetic acid form hydrogen and carbon dioxide by Clostridium species ATCC 29792. Chem. Eng. Commun.45,61-73.

30. Shi, D. L., Wei, X. Y., Fan, X., Zong, Z. M., and Chen, B., et al., (2013). Characterizations of the Extracts from Geting Bituminous Coal by Spectrometries. Energy Fuels. 27, 3709-3717.

31. Singh, K., and Zondlo, J., (2017). Characterization of fuel properties for coal and torrefied biomass mixtures. Journal of the energy institute. 90, 505-512.

32. Sonibare, O. O., Haeger, T., and Foley, S. F.,( 2012). Structural characterization of Nigerian coals by Xray diffraction, Raman and FTIR spectroscopy. Energy, 35, 5347-5353. 
33. Spring, S., Schumann, P., and Spro“er., (2005). Methanogeniumfrittonii Harris et al. 1996 is a later synonym of Methanoculleusthermophilus (Rivard and Smith 1982) Maestrojua'n et al. 1990. Int. J. Syst. Evol. Microbiolo; 55,1097-1099.

34. Stephen, A., Adebusuyi, A., Baldygin, A., Shuster, J., and Southam, et al., (2014).Bioconversion of coal: new insights from a core flooding study. RSC Adv. 4, 22779.

35. Tan, J. P., Jahim, J. M., Wu, T. Y., Harun, S., Mumtaz, T., (2016). Use of corn steep liquor as an economical nitrogen source for biosuccinic acid production by Actinobacillus succinogenes. International Conference on Chemical Engineering and Bioprocess Engineering. 36,012058.

36. Ulrich, G., and Bower, S., (2008). Active methanogenesis and acetate utilization in Powder River Basin coals, United States. Int. J. Coal Geol. 76, 25-33.

37. Verstraete, W., Assche, P. V., Devocht, M., and Baere, L. A. D., (1984). Influence of high $\mathrm{NaCl}$ and high $\mathrm{NH}_{4} \mathrm{Cl}$ salt levels on methanogenic associations. Water Res.18, 543-548.

38. Wagner, O., Hohlbrugger, P., Lins, P., and Illmer, P., (2012). Effects of different nitrogen sources on the biogas production - a lab-scale investigation Andreas. Micro biol. Res 167,630-636.

39. Wang, B., Tai, C., Wu, L., Chen, L., and Liu, J., et al., (2017). Methane production from lignite through the combined effects of exogenous aerobic and anaerobic microflora. Int. J. Coal Geol. 173, 84-93.

40. Wang, Q., Guo, h., Wang, H., Urynowicz, M. A., and Hu, A., et al., (2019). Enhanced production of secondary biogenic coalbed natural gas from a subbituminous coal treated by hydrogen peroxide and its geochemical and microbiological analyses. Fuel. 236, 1345-1355.

41. Wayne, P. A., (2003). National Committee for Clinical laboratory Standards (NCCLS), Methods for Dilution Antimicrobial susceptibility tests for bacterial that grow aerobically, $6^{\text {th }}$ edn. Approved Standard M7-A6

42. Wolfe, R. S., (1996). 1776-1996: Alessandro Volta's Combustible Air. ASM News 62,529-534

43. www.energyjustice.net "Burning waste coal is much more polluting that burning coal"

44. Yang, F., Li., W., Sun, M., Li, Q., Wang, M., and Sun, Y., (2018). Improved buffering capacity and methane production by anaerobic Co-digestion of corn stalk and straw deploymerization waste water. Energies. 11:1751.

45. Yang, J. I., Gang, L. I. U., Jing, M. A., Bin, Z. G., and Hua, X., (2014). Effects of Urea and Controlled Release Urea Fertilizers on Methane Emission from Paddy Fields: A Multi-Year Field Study. Pedosphere. 24, 662-673.

46. Zellner, G., Messner, P., and Stackebrandt, E., (1998). Methanoculleuspalmolei sp. nov., an irregularly coccoid methanogen from an anaerobic digester treating wastewater of a palm oil plant in NorthSumatra, Indonesia.Int J Syst Bacteriol 48, 1111-1117.

47. Zhang, X., Zhang, S., Li, P., Ding, Z., and Hao Z., (2018). Investigation on solubility of multicomponents from semi-anthracite coal and its effect on coal structure by fourier transform infrared spectroscopy and $x$ ray diffraction. Fuel processing technology. 174, 123-131. 
48. Zhou, C., Liu, G., Cheng, S., Fang, T., and Lam, P. K. S., (2014). Thermochemical and trace element behavior of coal gangue, agricultural biomass and their blends during co-combustion. Bioresources Technology. 166,243-251

49. Zhu, C., Zhang, J., Tang, Y., Xu, Z., and Song, R., (2011). Diversity of methanogenicarchaea in a biogas reactor fed with swine feces as the mono-substrate by mcrA analysis. Microbiol Res 166,2735 .

\section{Figures}

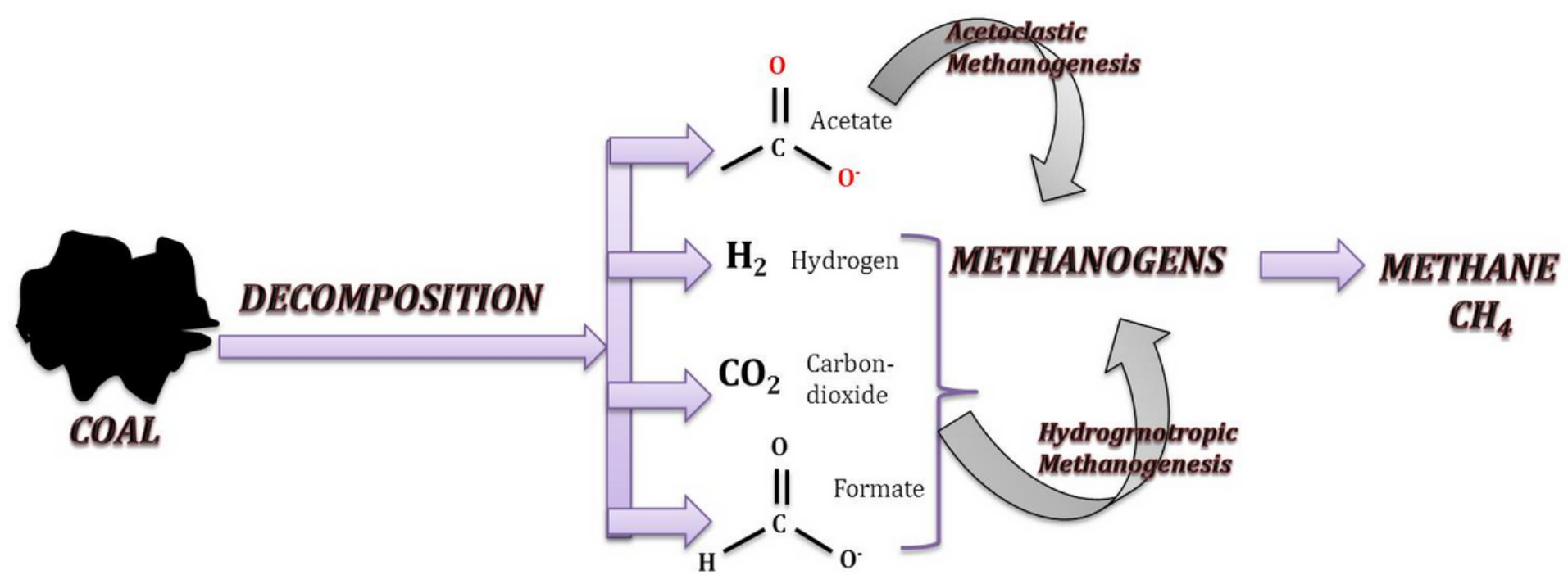

Figure 1

Schematic demonstration of microorganism interactions in the bio-conversion process of coal to methane. 


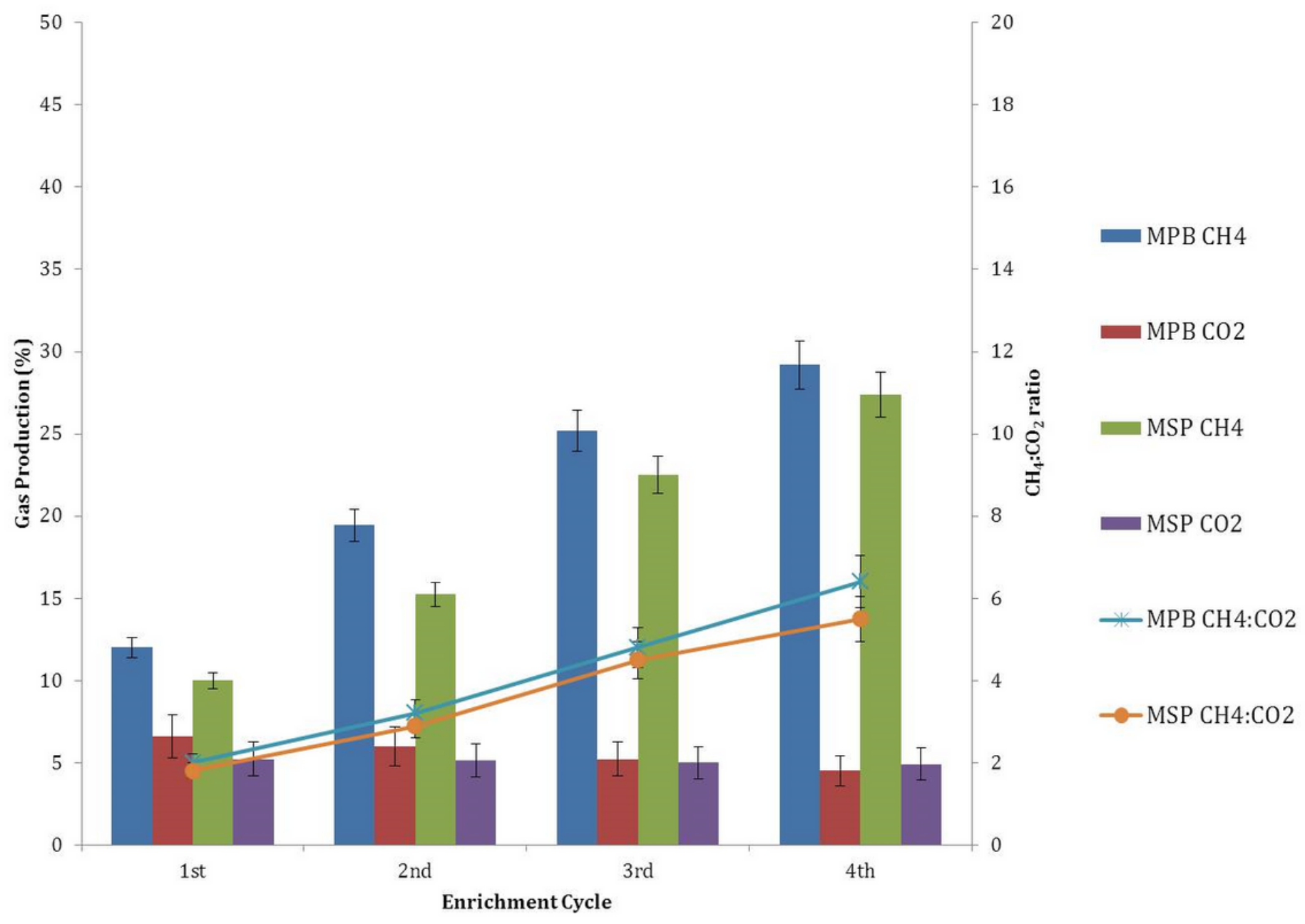

Figure 2

Explained the percent of gas generation by developed consortia in MSP and MPB medium where waste coal was used as carbon source in various enrichment cycles. Data recorded after 20 days of incubation. 

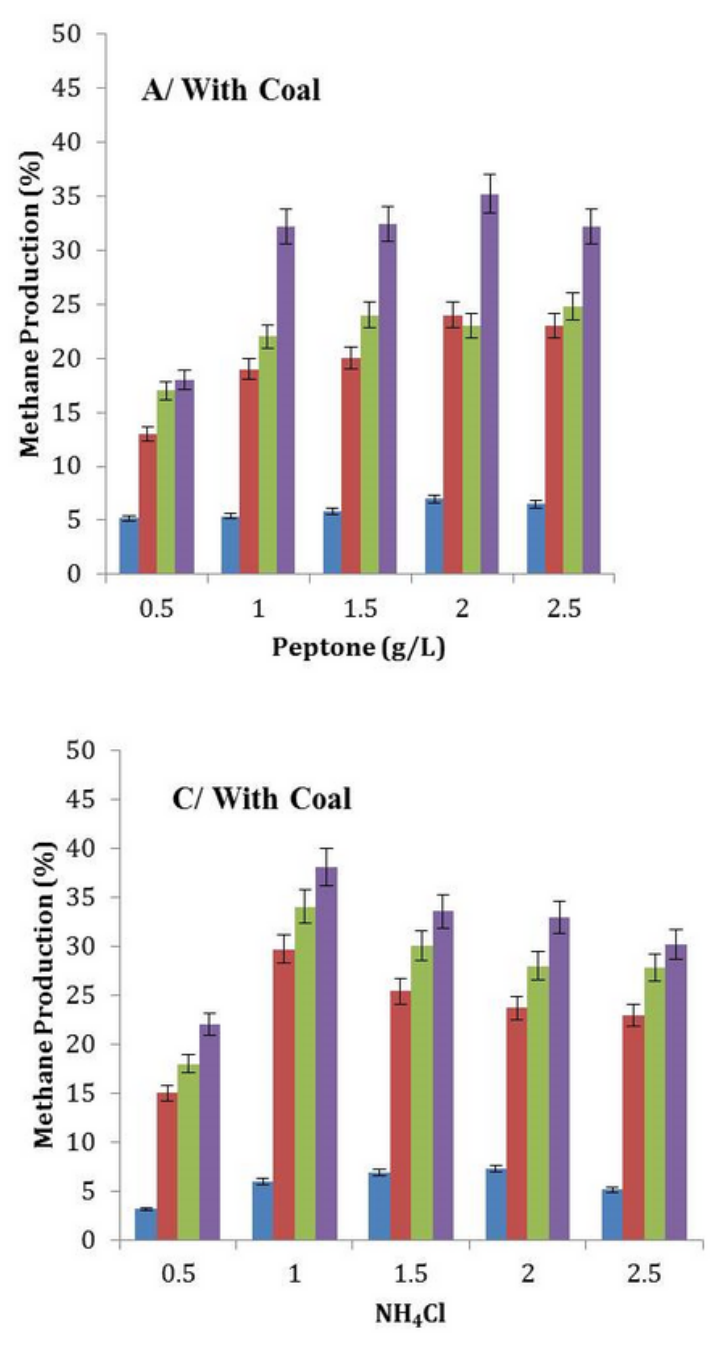

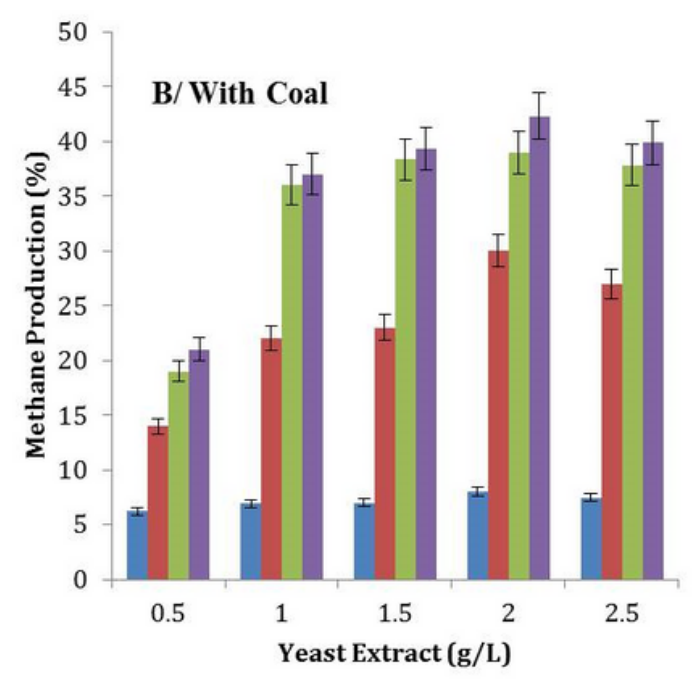

-5th day

10th day

"15th day

-20th day

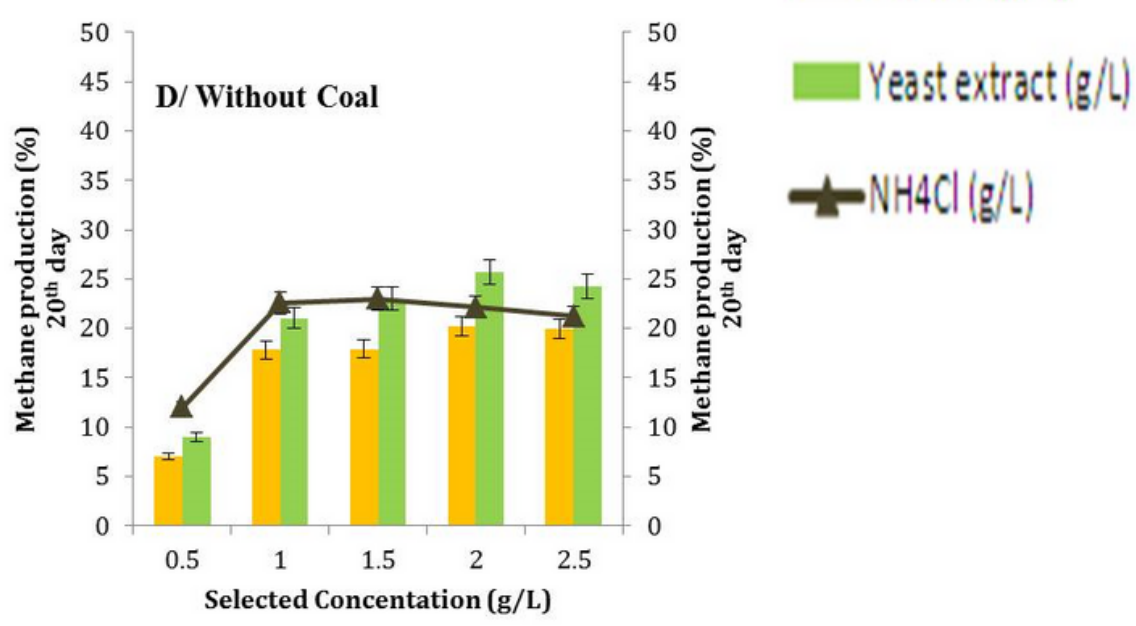

\section{Figure 3}

$\mathrm{A}, \mathrm{B}$ and $\mathrm{C}$; revealed the methane gas production in peptone, yeast extract and $\mathrm{NH} 4 \mathrm{Cl}$ selected components from MPB medium in range of $0.5-2.5 \mathrm{~g} / \mathrm{L}$ with coal $(1.0 \% \mathrm{w} / \mathrm{v})$. Whereas $\mathrm{D}$; depicted the methane production without coal 

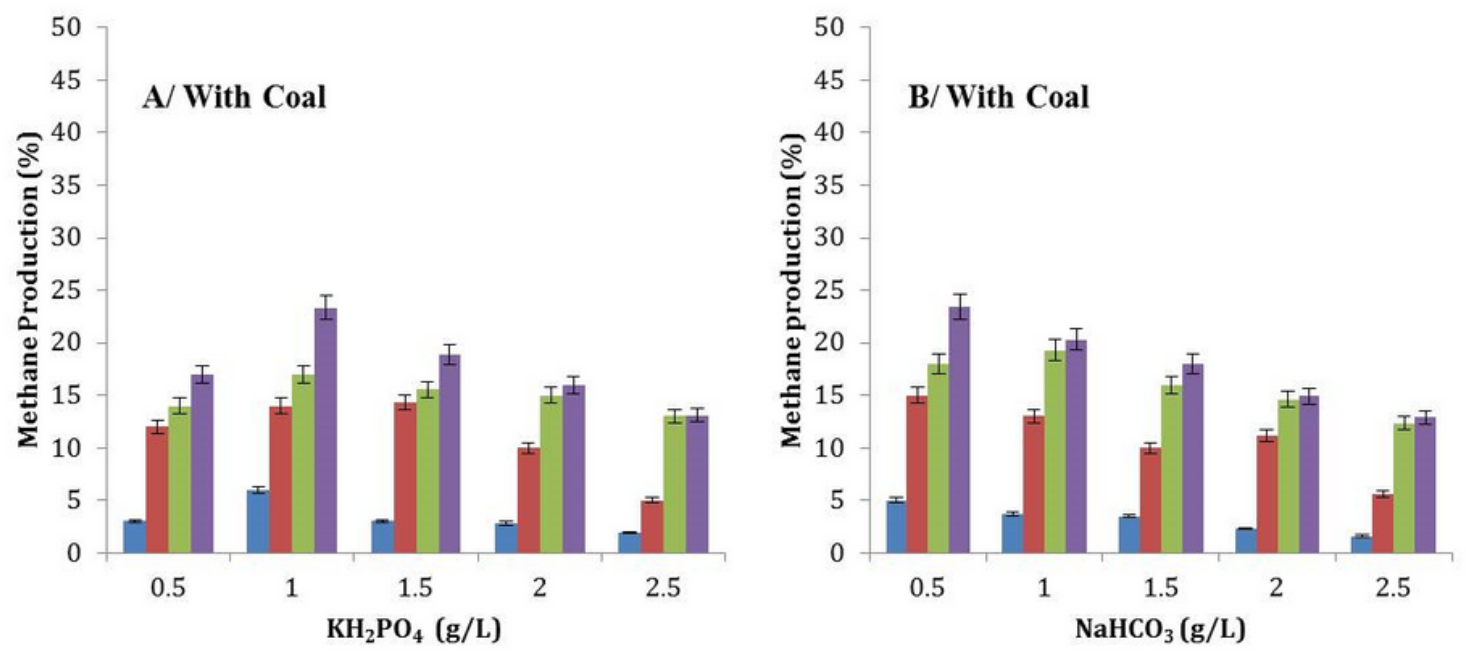

-5th day

I10th day

15th day

-20th day
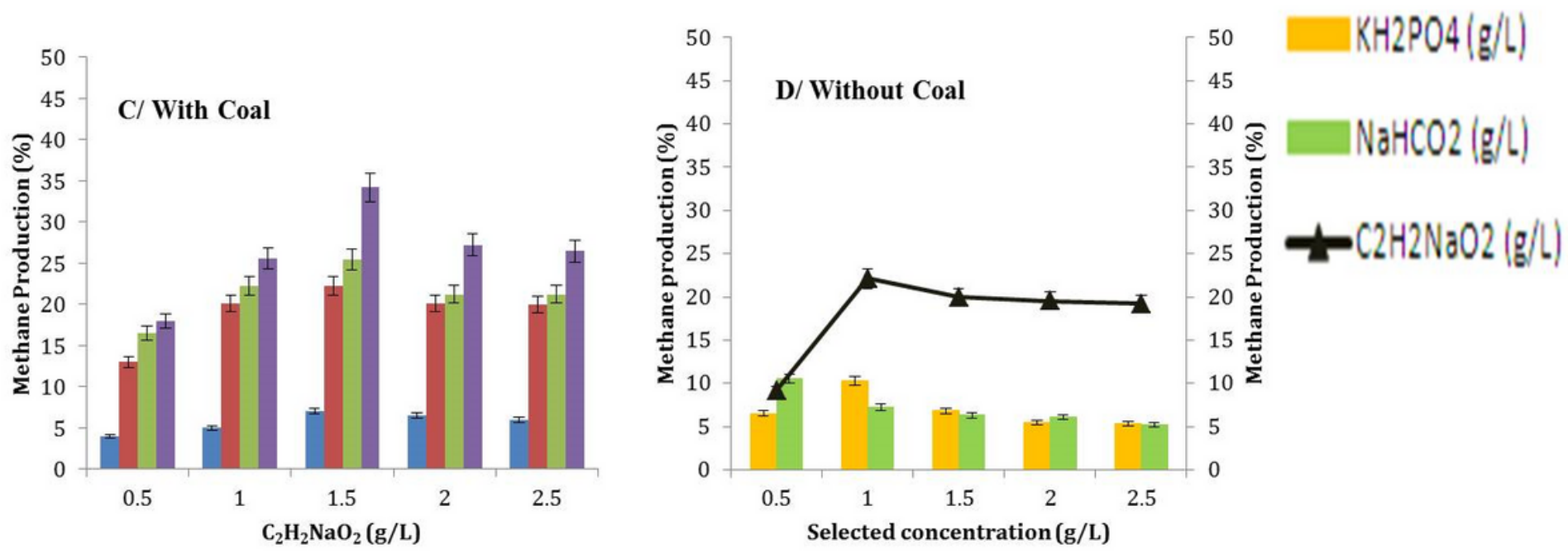

Figure 4

A, B and C; demonstrated the methane gas production in $\mathrm{KH} 2 \mathrm{PO} 4, \mathrm{NaHCO} 3$ and $\mathrm{C} 2 \mathrm{H} 2 \mathrm{NaO} 2$ selected components from MSP medium in range 0.5-2.5 g/L with coal (1.0\% w/v). Whereas D; depicted the methane production without coal. 


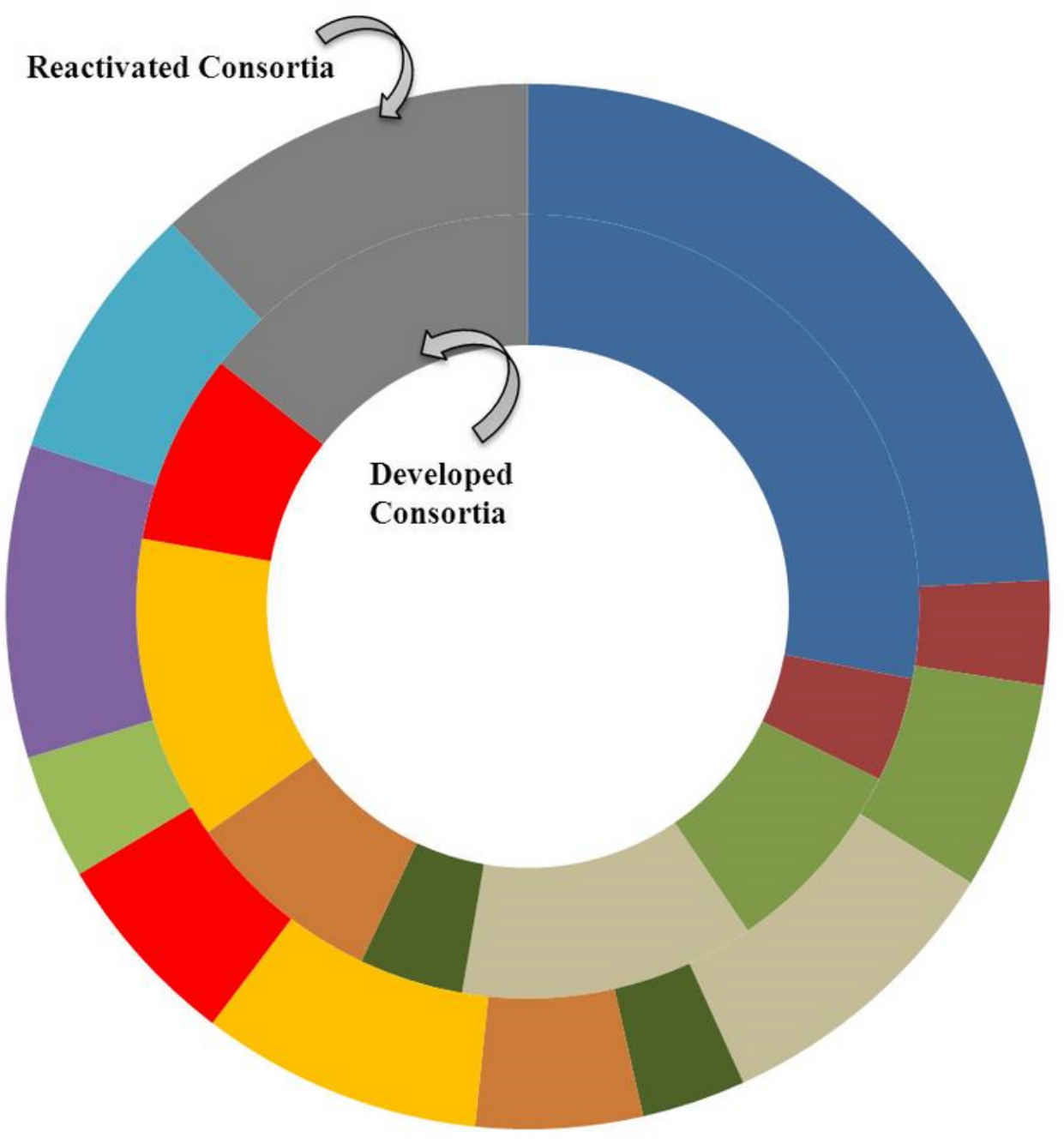

a.thermophilus/CBM65-Methanogen (AB065297)

-M.chikugoensis (AB038795)

M.marisnigri (AF531178)

M.submarinus (AF531178)

- M.olentangyi (AF09527)

M. bourgensis (AY196674)

M.receptaculi(DQ787476)

- M.palmaeoli (Y16382)

ఐ Pseudomonas sp. (GQ988399)

" Clostridium sp. (M98449)

n Clostridium beijerinckii (AY644457)

n Comamonas sp. (MF073320)

Figure 5

Depicted the pie-chart of the microbial community present in reactivated consortia and developed consortia. 


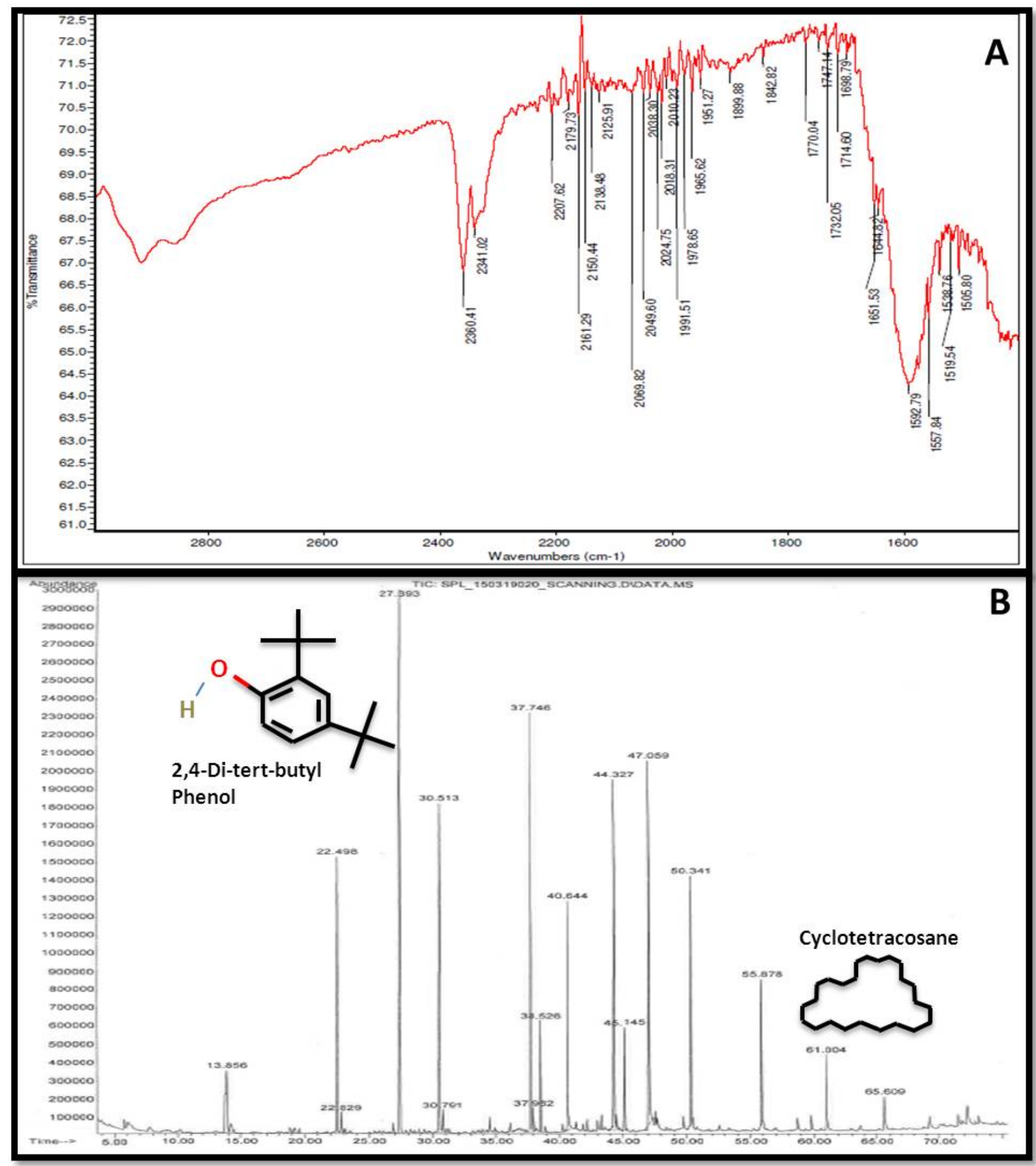

Figure 6

A; Illustrated the FTIR spectra of coal sample B; Demonstrated the fragmentation pattern of coal sample. 


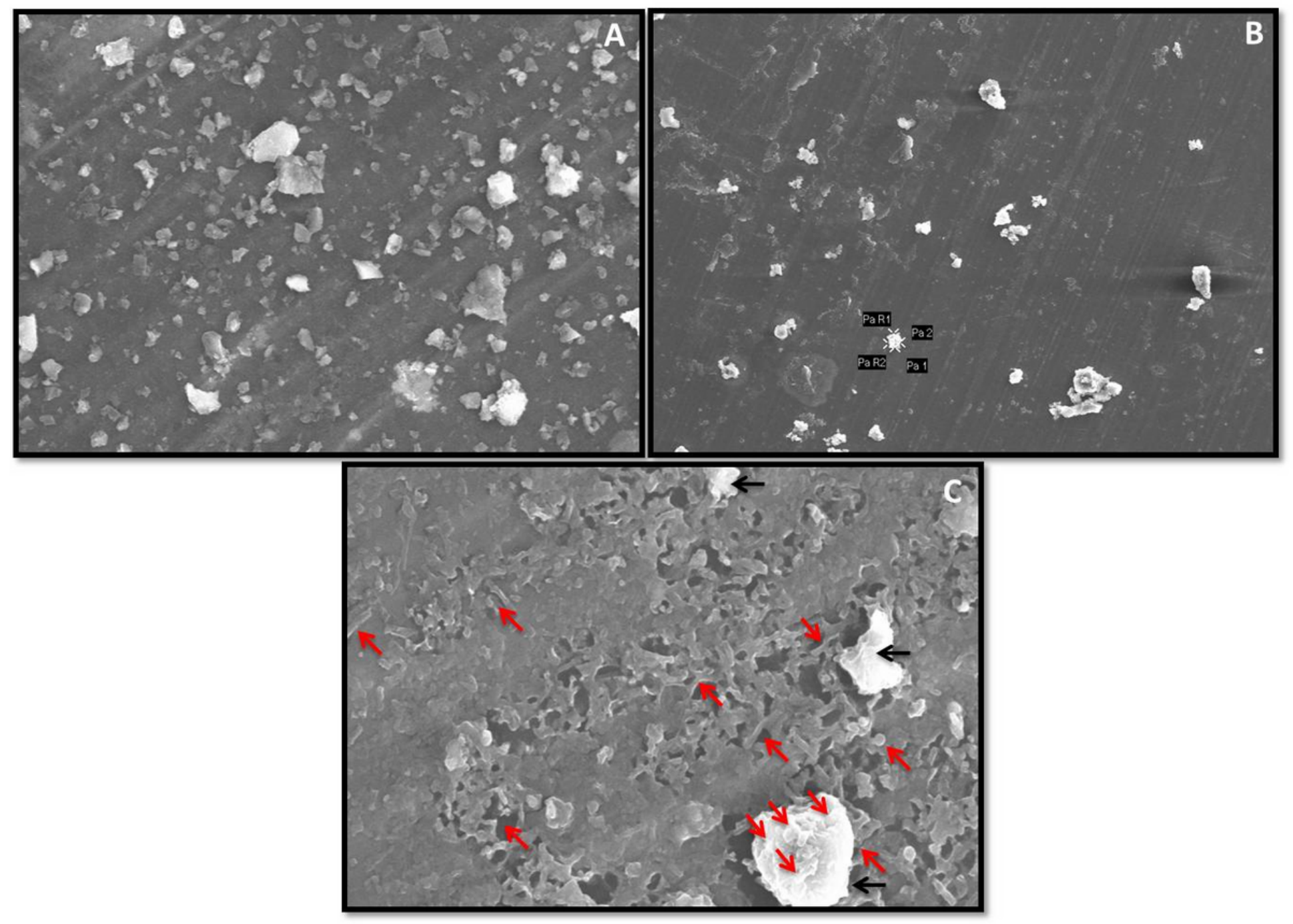

Figure 7

A, Depicted the untreated (before bacterial treatment) coal particles (scale bar $2 \mu \mathrm{m}$ ). B; represented the treated (after bacterial treatment) coal particles (scale bar $2 \mu \mathrm{m}$ ). C; illustrated the interaction between bacteria and coal particle (scale bar $2 \mu \mathrm{m}$ ). 


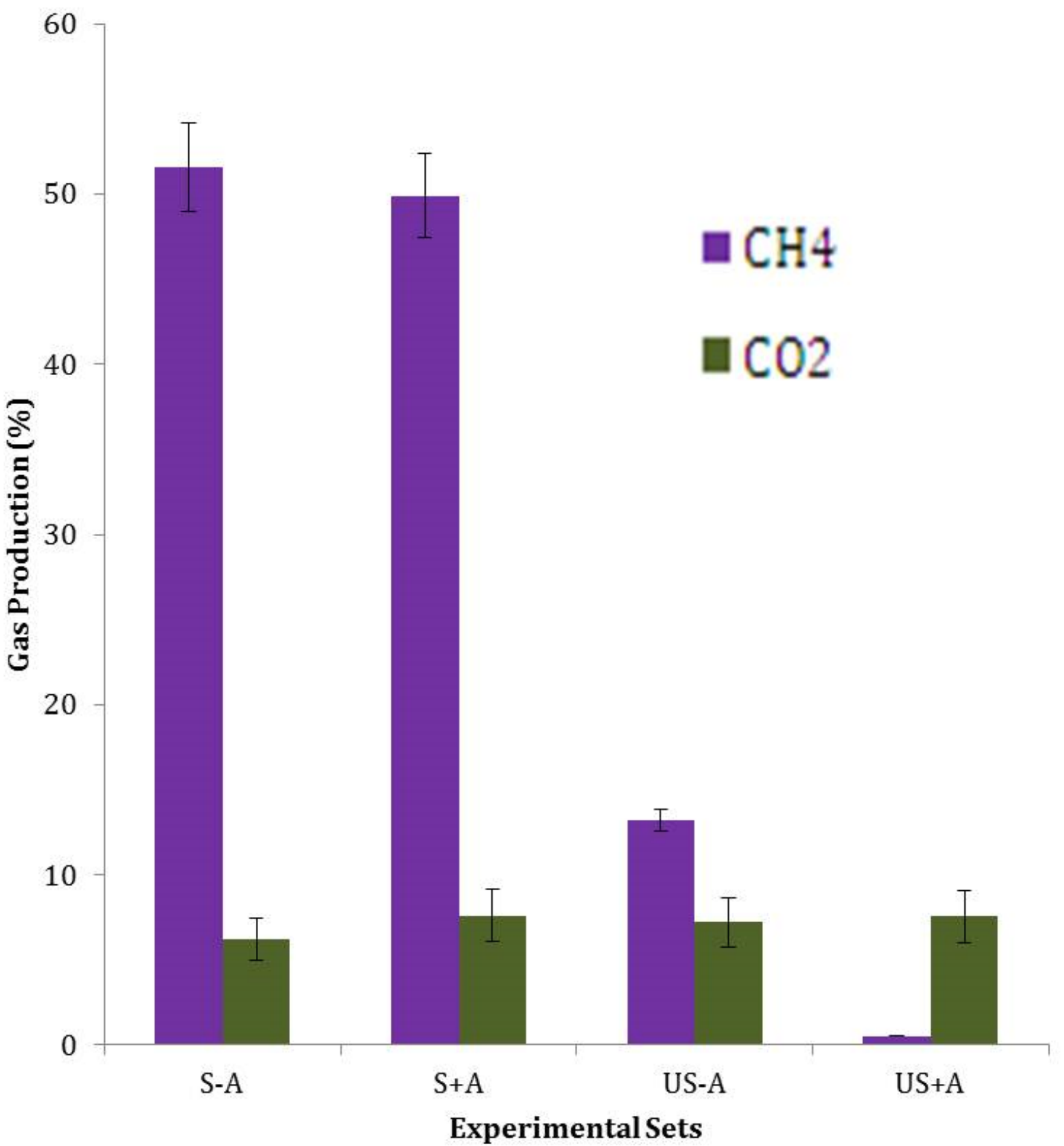

\section{Figure 8}

Depicted the compatibility test in modified medium with waste coal and tube well water (Set 1: S-A, where S signify Nitrogen sparge media (anaerobic) and -A represent without autoclave media; Set 2: S+A, where $S$ signify nitrogen sparge media and $+A$ represent Autoclave media; Set 3: US-A, where US signify without sparging media (aerobic) and -A represent without Autoclave media; Set 3: US+A, where US signify without sparging media (aerobic) and +A represent autoclave media. 


\section{Supplementary Files}

This is a list of supplementary files associated with this preprint. Click to download.

- Graphicalabstract.jpg

- Supplementary.rtf 